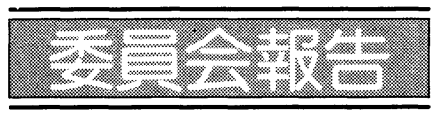

\title{
新しく提案された土木学会規準（案） \\ PROPOSED JSCE CONCRETE STANDARDS (DRAFT)
}

\author{
規準関連小委員会 \\ By Sub-Committee for Concrete Standards
}

規準関連小委員会は，コンクリート委員会の一小委員 会として設けられたものであり，コンクリート工学に関 する各種規準の提案, 改廃等の原案を作成し, 常任委員 会で承認の得られたものをまとめて「コンクリート標準 示方書」で公表している. しかし，土木学会規準として 制定されたものは早く利用できることが望ましいため, 新たに提案または改廃された土木学会規準を順次, 論文 集（第 5 部門）で公表することが常任委員会で了承され た。

1988 年末までに，規準関連小委員会で審議し，常任 委員会で承認された新しい土木学会規準および改廃され た土木学会規準は, 以下の 3 つである.

1）廃止された土木学会規準

アアルミナセメントの凝結および強さ試験方法 (JSCE-1972)

2) 新たに提案された土木学会規準

○抜き試験による鉄筋とコンクリートとの付着 強度試験方法（案）（JSCE-1988）

$\bigcirc$ コンクリートの静弾性係数試験方法（案） (JSCE-1988)

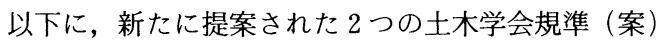
を示す. 本規準 (案) に対し意見のある方は 3 月末日ま でに規準関連小委員会あて文書で提出されたい.

なお,当規準関連小委員会では,さらにテストハンマー によるコンクリート強度, コンクリート用材料に含まれ る塩化物含有量, コンクリート用練りまぜ水等に関する 試験方法や品質規準等を継続審議中である.

（文責：規準関連小委員会幹事 魚本健人）

\section{コンクリートの静弾性係数試験方法（案）}

1. 適用範囲この規準は, 静的な圧縮力を受けるコ ンクリート円柱供試体の縦方向の弾性係数を求める試験 方法に適用するものであり，次の異なる方法がある.

A） 単調増加載荷により静弾性係数を求める方法

B）繰り返し載荷により静弾性係数を求める方法

参考 JIS A 1170 (コンクリートからのコア及びは りの切り取り方法及び強度試験方法）によっ て採取したコンクリートコア供試体の弾性係 数はこの規準に準じて行うとよい.

2. 用語の意味 この規準で用いる主な用語の意味は次 のとおりとする.

2.1 静弾性係数 供試体の応力ひずみ曲線において, 最大荷重の $1 / 3$ の点とひずみが $50 \times 10^{-6}$ の点とを結ぶ 線分の勾配で示す.

2.2 検 長 供試体のひずみを検出する長さ.

\section{3. 試験用機械器具}

3.1 圧縮試験機はJIS B 7733 （圧縮試験機）に規定 するものとする. また，上下の加圧板の圧縮面はみがき 仕上げとし, その平面度(1) のショア硬さ $H_{s}$ は70 以上でなければならない.

注( 1 ) ここでいう平面度は, 平面部分の最も高い ところと最も低いところを通る2つの平行 な平面を考え，この平面間の距離をもって 表わす.

3.2 ひずみ測定器具は $10 \times 10^{-6}$ よりよい精度で測定 できるものとする. また, ひずみ測定器具の検長は, コ ンクリートに用いた粗骨材の最大寸法の 3 倍以上, かつ 供試体の高さの $1 / 2$ 以下とする. 
備考 1 ひずみの測定には, 一般に次の器具が用い られている.

(1) コンプレッソメータ

（2）抵抗線型ひずみ測定器

4. 供 試 体 供試体はJIS A 1132 （コンクリート の強度試験用供試体の作り方）の 4. によって作るもの とする。

供試体の数は同一条件 ${ }^{(2)}$ の試験に対して 3 個以上とす る.

注（２）この条件には, 配合, 供試体の寸法, 養生 方法，試験材令などがある。

\section{5. 試験方法}

\section{1 準備}

（1）供試体は原則として，所定の養生を終った直後 の状態で試験ができるようにしなければならな い.

（2）試験用機械器具は正常な状態で使用できるよう に準備しなければならない。

5.2 ひずみ測定器具の取付け ひずみ測定器具は供 試体の軸に平行，かつ対称な $2 つ$ 線上で，供試体の高 さの $1 / 2$ の位置を中心に取り付ける.

\section{3 載荷の準備}

（1）試験は温度および湿度の変化の少ない室内で行 う。

（2）最大荷重がひょう量の $1 / 2$ からひょう量までの 範囲になるように試験機のひょう量を選定す る.

備考 2 最大荷重が不明な場合は，あらかじめ JIS A 1108 (コンクリートの圧縮強度試験方法) に準じて試験を行うとよい.

（3）供試体は偏心載荷とならないよう，その中心軸 が試験機の加圧板の中心線に一致するように置 $<$.

\section{4 載荷試験}

5.4.1 単調増加載荷により静弾性係数を求める場 合

（1）載荷は中断することなく行う. 荷重を加える速 度は，標準として毎秒 $2 \sim 3 \mathrm{kgf} / \mathrm{cm}^{2}$ とする。

（2）ひずみ量は，原則として最大荷重の $1 / 2$ まで測 定し，その荷重間隔は等間隔で少なくとも 10 点記録できるように選定する。

（3）供試体が破壊するまでに，試験機が示す最大荷 重を有効数字 3 析まで読む.

5.4 .2 繰り返し載荷により静弾性係数を求める場 合

（1）載荷は中断することなく行う. 荷重を加える速 度は，標準として毎秒 $2 \sim 3 \mathrm{kgf} / \mathrm{cm}^{2}$ とし，除
荷する速度はその 2 倍を越えないものとする.

（2）上限荷重として，まず，最大荷重のほぼ $1 / 3$ の 荷重段階までの載荷を行ったのち除荷する．こ の間はひずみ計の作動が正常であることを確認 し，さらに上限荷重のときのひずみ量を記録す る.

備考 3 この方法による場合は，備考 2 に示すよう な方法であらかじめ最大荷重を推定してお $<$.

（3）第 2 回以降は初回載荷の上限荷重までの載荷を 行った後直ちに除荷する。このとき，載荷時の ひずみが $50 \times 10^{-6}$ に相当するときの荷重およ び上限荷重時のひずみを読み取る。上限荷重時 のひずみの読みが，その前の回の載荷時のひず みの読みより $20 \times 10^{-6}$ より大きく異なる場合 にはこの操作を再度繰り返す。このときは，計 測が何回目のものであるかを同時に記録する.

\section{6. 結果の計算}

6.1 単調増加載荷により静弾性係数を求める場合

（1） 5.4 の結果より，各供試体ごとに応力-ひずみ 曲線を作成する（図一1参照）.

（2）静弾性係数は次式で計算し，有効数字 3 析まで 求める.

$E_{1}=\frac{S_{1}-S_{2}}{\varepsilon_{1}-50 \times 10^{-6}}$

ここに, $E_{1}$ : 単調増加載荷により求めた静弾性係数 $\left(\mathrm{kgf} / \mathrm{cm}^{2}\right)$

$S_{1}$ : 最大荷重の $1 / 3$ に相当する応力 $\left(\mathrm{kgf} / \mathrm{cm}^{2}\right)$ $S_{2}$ :ひずみ $50 \times 10^{-6}$ のときの応力 $\left(\mathrm{kgf} / \mathrm{cm}^{2}\right)$

$\varepsilon_{1}$ : 応力 $S_{1}$ によって生ずるひずみ

6.2 繰り返し載荷により静弾性係数を求める場合 静弾性係数は次式で計算し,有効数字 3 析まで求める.

$E_{2}=\frac{S_{1}-S_{2}}{\varepsilon_{1}-50 \times 10^{-6}}$

ここに, $E_{2}$ : 繰り返し載荷により求めた静弾性係数 $\left(\mathrm{kgf} / \mathrm{cm}^{2}\right)$

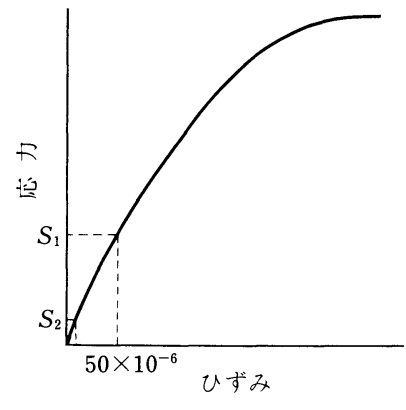

図一1 応カーひずみ曲線 
$S_{1}:$ 繰り返しの上限荷重に相当する応力 $\left(\mathrm{kgf} / \mathrm{cm}^{2}\right)$

$S_{2}$ : 最終載荷のときのひずみ $50 \times 10^{-6}$ のとき の応力 $\left(\mathrm{kgf} / \mathrm{cm}^{2}\right)$

$\varepsilon_{1}$ : 最終載荷のときの応力 $S_{1}$ によって生ずる ひずみ

備考 4 載荷回数は最も少ない場合は 2 回であり, 通常は 3 回で十分である.

7. 報 告 報告には次の事項のうち必要なものを 記載する.

（1）載荷の方法, 繰り返しの場合はその回数

(2) 供試体の番号

（3）材令（日）

(4) 使用材料

（5）供試体の寸法 $(\mathrm{cm})$

（6）養生方法および養生温度

（7）ひずみ測定器具の種類, 検長 $(\mathrm{mm})$

（8）最大荷重（kgf）または圧縮強度 $\left(\mathrm{kgf} / \mathrm{cm}^{2}\right)$

（9）応力ーひずみ曲線

(10) 静弾性係数 $\left(\mathrm{kgf} / \mathrm{cm}^{2}\right)$

（11）供試体の破壊状況

(12）その他

[参 考] 単調増加載荷による場合は初載荷を受ける 部材の静弾性係数の推定等に用いることができる.

繰り返し載荷による場合は供用され載荷が繰り返され ている部材の静弾性係数の推定などに用いることができ る.

\section{引抜き試験による鉄筋とコンクリートとの 付着強度試験方法（案）}

1. 適 用範 囲この規準は，引抜き試験によって鉄筋 コンクリート用異形棒鋼（以下，鉄筋という）の付着性 能を試験する場合について規定する(1).

注（1）コンクリートの付着強度を試験する場合 も，この方法に準じて行うことができる。

備考この規格の中で（）をつけて示してある単 位および数值は，国際単位系（SI）による ものであって，参考として併記したものであ る.

\section{表-1 供試体の寸法}

\begin{tabular}{|c|c|c|c|}
\hline 鉄筋の呼び名 & $\begin{array}{c}\text { 供試体の一辺の長さ } \\
B(\mathrm{~cm})\end{array}$ & 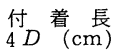 & $\begin{array}{c}\text { 非付着長 } \\
(\mathrm{cm})\end{array}$ \\
\hline D 16 & 10 & 6.4 & 3.6 \\
\hline D 25 & 15 & 10.2 & 4.8 \\
\hline D 32 & 20 & 12. 7 & 7.3 \\
\hline D 41 & 25 & 16. 5 & 8.5 \\
\hline D 51 & 30 & 20.3 & 9.7 \\
\hline
\end{tabular}

\section{2. 供 試 体}

2.1 供試体は表一1に示す立方形供試体とし，表に 示す寸法以外の鉄筋を試験する場合には，一辺を鉄筋の 公称直径（以下，鉄筋の直径という）の 6 倍とする.

2.2 鉄筋とコンクリートの付着区間は，文字などの 特別な圧延マークのない部分とし，自由端側に設け，そ の長さは鉄筋の 4 倍とする.

2.3 載荷板からの応力の均等化を図るために, 載荷 端側に鉄筋の直径の 2 倍の長さの非付着区間を設けるも のとする.

2.4 自由端側の鉄筋突出長さは $5 \mathrm{~mm}$ 程度とし, ダ イヤルゲージが接する端面は，鉄筋軸に垂直で平滑な面 に仕上げる.

2.5 供武体の数は 3 個とする.

2.6 引抜き試験用供試体と同時に, JIS A 1132 （コ ンクリートの強度試験用供試体の作り方）によって圧縮 強度試験用供試体を作る。

3. 型 わく

3.1 型わくは金属製とし, 寸法の誤差は各辺長の 1/100 以下とする．供試体の載荷面に接する側板の平面 度 ${ }^{(2)}$ は $0.02 \mathrm{~mm}$ 以内とする.

注(2) ここでいう平面度は, 平面部分の最も高い ところと最も低いところを通る 2 つの平行 な平面を考え，この平面間の距離をもって 表わす。

3.2 供試体の載荷面に接する側板に鉄筋が通る開口 部を設け，相対する側板に鉄筋を支持するくぼみを設け
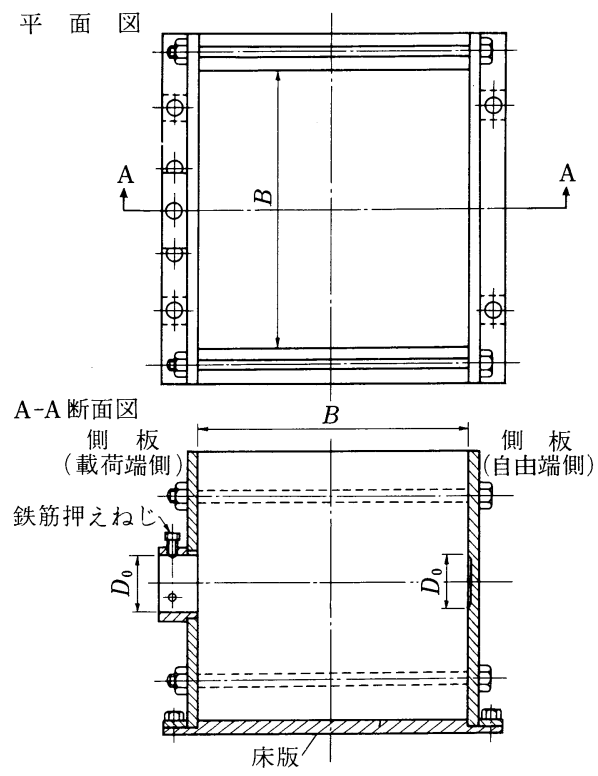

注） $D_{0}$ : 鉄筋最外径, $B$ : 供試体の一辺の長さ

図一1 引抜き試験供試体用型わく 
る. 図一 1 に型わくの例を示す.

3.3 型わくは継ぎ目に油土，硬いグリースなどを薄 く付けて組み立て，漏水しないようにしなければならな い. 型わくの内面には，コンクリートを打ち込む前に鉱 物性の油を塗る.

4. コンクリートの品質 コンクリートは粗骨材の最大 寸法を, $20 \mathrm{~mm}$ または $25 \mathrm{~mm}$ の普通骨材とし，スラン プを $10 \pm 2 \mathrm{~cm}$ ，材令 28 日における圧縮強度を $300 \pm 30$ $\mathrm{kgf} / \mathrm{cm}^{2}\left(29.4 \pm 2.9 \mathrm{~N} / \mathrm{mm}^{2}\right)$ とする.

\section{5. コンクリートの打込み}

5.1 付着区間の鉄筋表面を清掃し，さび，油類，污 れ等を取り除く.

5.2 鉄筋の非付着区間となる部分にあらかじめコン クリートとの付着を絶つための適当な処置 ${ }^{(3)}$ を施し，鉄 筋が載荷面に垂直となるようにして型わく内に水平に設 置(4)する。

注（３）鉄筋の最外径とほぼ等しい内径の軟質ビ ニール管とオイルパテ等で被覆するとよ

い. 被覆部分の外径は，鉄筋の直径の 1.2 ～1. 5 倍とする.

注 $(4$ ) リブが鉄筋の軸を含む水平面に位置するよ う設置するのを標準とする。

5.3 鉄筋を通した開口部のすき間は，オイルパテ等 を用いて漏水しないようにしなければならない。

5.4 型わくはコンクリートを打ち込む際，および打 ち込んでから型わくを取り外すまで，水平な場所に置か なければならない。

5.5 コンクリートは一層の厚さを $10 \mathrm{~cm}$ 以下とし て，ほぼ相等しい層に分けて打ち込む.コンクリートは 各層ごとに型わくの軸にほぼ対称となるように詰める.

5.6 突き棒 ${ }^{(5)}$ を用いて締め固める場合，コンクリー

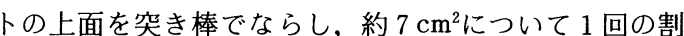
合で突く.

各層ごとに突き終わったのち，必要に応じて型わくの 面に沿ってスページングを行い，型わくの側面を軽くた たいて，突き棒によってできた究がなくなるようにしな ければならない。

注（5）突き棒は先端を半球状とした直径 $16 \mathrm{~mm}$, 長さ $50 \mathrm{~cm}$ の丸鋼とする.

5.7 内部振動機 ${ }^{(6)}$ によって締め固める場合, コンク リート上面約 $60 \mathrm{~cm}^{2}$ について 1 回の割合で差し込むも のとし，振動機が鉄筋に接触しないようにしなければな らない，上層を締め固める場合には，振動機を下層に約 $3 \mathrm{~cm}$ 差し込むようにする. 最上層のコンクリートは, 振動機を差し込む際にモルタルがあふれ出るほどいっぱ いに詰め込んではならない。

振動機はゆっくり引き抜き，あとに空が残らないよう
にする.コンクリートが十分に締め固められたのち， 5.6 に準じてスページングを行い，型わくの側面をたた $<$.

注（6）振動機は JIS A 8610 (コンクリート棒形 振動機）に規定するもので，公称棒径 27 $\mathrm{mm}$ を用いる。

5.8 打込みが終わったのち, 上面の余分のコンクリー 卜をかき取り，ほぼ平らに仕上げ，約 2 時間後に再仕上 げを行い, 正しい所定の寸法の供試体になるようにする.

6. 型わくの取外しおよび養生 型わくは材令 2 日にお いて取り外し (7)，その後, 試験時まで $20 \pm 3^{\circ} \mathrm{C}$ の水中で 養生する。

注（7）鉄筋に衝撃を与えないように注意しなけれ ばならない。

\section{7. 試験方法}

7.1 引張試験機は JIS B 7721（引張試験機）に規定 するものとする。

7.2 供試体を載荷板上に正しく据え，その下に球座 を置き，供試体に偏心荷重が加わらないようにしなけれ ばならない。

7.3 載荷板の穴の直径は鉄筋の直径の 2 倍を原則と する．載荷板および球座の寸法を図一2に例示する.

7.4 荷重は衝撃を与えないように，なるべく一様な 速度で加えなければならない，載荷速度は鉄筋の引張応 力度が毎分 $500 \mathrm{kgf} / \mathrm{cm}^{2}\left(49.0 \mathrm{~N} / \mathrm{mm}^{2}\right)$ 以下となるよう にする.

7.5 鉄筋の自由端に取り付けるダイヤルゲージは, JIS B 7509 (0.01 mm 目盛ダイヤルゲージ) に規定す るものを用いる.

ダイヤルゲージの固定方法の例を図一2に示す.

7.6 表一2に従って各すべり量に対する荷重を読み 取る。

7.7 すべり量が $0.002 D$ に達したときの荷重および 最大荷重 ${ }^{(8)}$ を記録する. ここに, $D$ は鉄筋の直径を示す.

注（８）破壊時にコンクリート片が落下したり，ダ イヤルゲージが破損したりしないように， 適当な処置をしておくのがよい.

7.8 試験を行う材令は 28 日とする.

\section{8. 結果の計算}

8.1 付着応力度を次の式で計算し, 有効数字 3 析ま で求め, 各供試体の付着応力度-すべり曲線を描く.

$$
\tau=\frac{P}{4 \pi D^{2}} \cdot \alpha
$$

ここに, $\tau$ ：付着応力度 $\left(\mathrm{kgf} / \mathrm{cm}^{2}\right)\left\{\mathrm{N} / \mathrm{mm}^{2}\right\}$

$P:$ 引張荷重 $(\mathrm{kgf})\{\mathrm{N}\}$

$D:$ 鉄筋の直径 $(\mathrm{cm})\{\mathrm{mm}\}$

$\alpha$ : コンクリートの圧縮強度に対する補正係数 

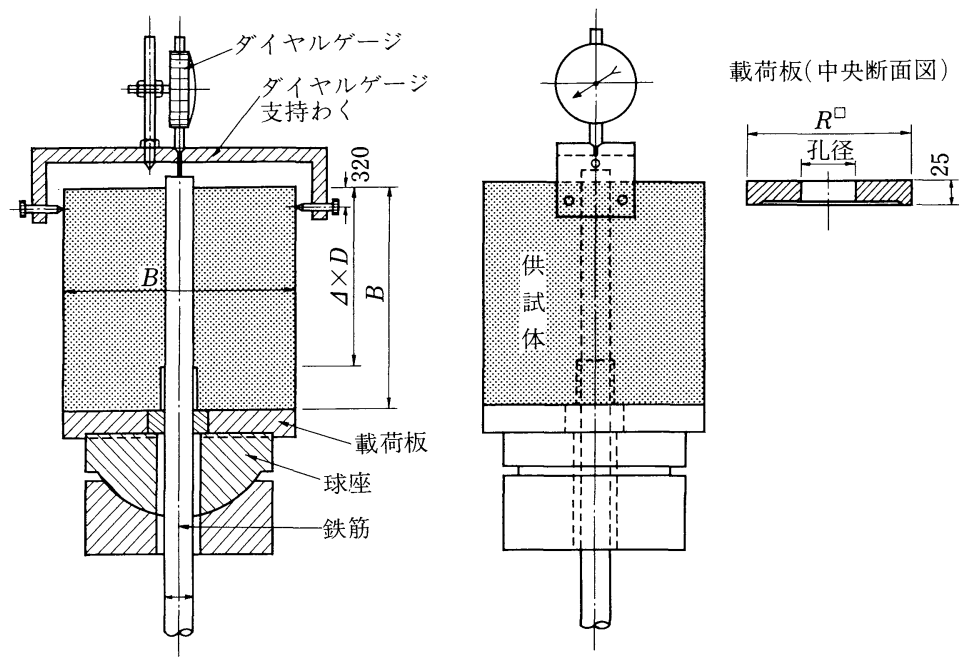

載荷板および球座の主な寸法

\begin{tabular}{|c|c|c|c|c|}
\hline \multirow{2}{*}{$\begin{array}{l}\text { 鉄筋の } \\
\text { 呼び名 }\end{array}$} & \multicolumn{2}{|c|}{ 載荷板 } & \multicolumn{2}{|c|}{ 球 座 } \\
\hline & 厚さ & 孔径 & 孔径 & 球 $r$ \\
\hline D16 & \multirow{5}{*}{25} & 32.0 & \multirow{3}{*}{55} & \multirow{3}{*}{75} \\
\hline D25 & & 51.0 & & \\
\hline D32 & & 63.5 & & \\
\hline D41 & & 82.5 & \multirow{2}{*}{86} & \multirow{2}{*}{120} \\
\hline D51 & & 101.5 & & \\
\hline
\end{tabular}

注） $D ：$ 公称直径

$B:$ 供試体の一辺の長さ

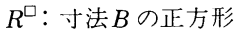

$r$ : 球座の球半径

図一2 引抜き試験用測定装置

\section{表一2 測定の間隔}

\begin{tabular}{|c|c|c|}
\hline \multicolumn{2}{|c|}{ 自由端すべり量の範 囲 } & 測 定 の 間 隔 \\
\hline & $0.1 \mathrm{~mm}$ 末満 & $0.01 \mathrm{~mm}$ \\
\hline $0.1 \mathrm{~mm}$ 以上 & $0.2 \mathrm{~mm}$ 未満 & $0.02 \mathrm{~mm}$ \\
\hline $0.2 \mathrm{~mm}$ 以上 & $0.5 \mathrm{~mm}$ 未満 & $0.05 \mathrm{~mm}$ \\
\hline $0.5 \mathrm{~mm}$ 以上 & & $0.1 \mathrm{~mm}$ ごと \\
\hline
\end{tabular}

$$
\alpha=300 / f_{c}^{\prime}\left\{29.4 / f_{c}^{\prime}\right\}
$$

$f_{c}^{\prime}$ : 同時に作製した円柱供試体の材令 28 日に おける圧縮強度 $\left(\mathrm{kgf} / \mathrm{cm}^{2}\right)\left\{\mathrm{N} / \mathrm{mm}^{2}\right\}$

8.2 すべり量が $0.002 \mathrm{D}$ における付着応力度を計算 する.

8.3 最大付着応力度は式（1）に最大荷重を代入し て計算する.

8.4 すべり量が $0.002 \mathrm{D}$ における付着応力度と最大 付着応力度は供試体 3 個の平均とする。

9. 報告 報告には, 下記の事項のうち必要なも のを記載する。
（1）供試体の番号

（2）供試体の寸法

（3）鉄筋の呼び径およびふしの形状，ふしの平均間 隔，ふしの高さと箪位重量の実測値 ${ }^{(9)}$

注 (9) 測定はJIS G 3112 (鉄筋コンクリート用 棒鋼）の 8.3（1）に規定する方法による.

（4）鉄筋の機械的性質

（5） コンクリートの配合，スランプ $(\mathrm{cm})$ および 圧縮強度 $\left(\mathrm{kgf} / \mathrm{cm}^{2}\right)\left\{\mathrm{N} / \mathrm{mm}^{2}\right\}$

（6）型わく内に設置したときのリブの位置

(7) 付着応力度-すべり曲線

（8）すべり量が $0.002 \mathrm{D}$ における付着応力度, 最 大付着応力度 $\left(\mathrm{kgf} / \mathrm{cm}^{2}\right)\left\{\mathrm{N} / \mathrm{mm}^{2}\right\}$ および破壊 状態

（9）その他

(1989.1.6 • 受付) 